shall be supplied in the next volume; those who take the trouble to note such omissa are the truest friends we have.

I, Savile Row, W.

$$
\text { E. C. RiE }
$$

[The writer of the review claims to know something of the difficulties the editor of the Zoulogical Record refers to, with which "haud ignarus mali" he sympathises, and still he clings to the idea that it might be expedient for the editor to keep his young team in hand, but in thus suggesting a uniformity in practice, nothing was further from his thoughts than an unfriendly criticism, As to the accentuation of the $d$ in infra, he quite agrees with the editor that he would find the fact he mentions in an "old Ainsworth," but no modern writer now ever thinks of using an accent on Latin words under any circumstances, and hence the query. As to Kalispongia, Wright, being spelt with a $K$ and not a $C$, though the subject is a tempting one for comment, yet a controversy on it would hardly be suited for the columns of NATURE, but surely the editor will draw a distinction between an attempt to preserve a uniformity in the style of the several records, and an insistance on anthors being uniform in their spelling of generic names.]

\section{A Museum Conference}

Mr. Paton's suggestion about a museum conference is an admirable one, although $I$ think that it should not be confined to officials only. The time has come when an Association for the Promotion and Systematic Arrangement of Museums must be formed. I trust, therefore, that those competent to do it will take the matter up and produce some practical result.

\section{J. ROMILLY ALLEN}

\section{The Tay Bridge Storm}

IN his interesting letter on the above subject (NATURE, vol. xxi. p. 443) Sir Ralph Abercromby remarks that "there is a good deal of evidence to show that where the velocity of the [cyclone] centre is very great, the strength of the wind for any give gradients is increased, or at all events becomes more squally and gusty;" and again (p. 444) that the Tay Bridge storm " was exceptionally squally and gusty, doubtless owing to the unusually rapid rate of its motion." I am far from wishing to be understood to impugn the accuracy of these remarks, but $I$ would say that the law which is indicated in them has, if I mistake not, escaped general observation, and I believe that meteorologists will be grateful to Sir R. Abercromby, than whom no one can be found better able to do so, if he will point out the evidence on which it rests.

It is, I think, generally arimitted that in traversing the continents both of Europe and of North America storms have on some oicasions a greater velocity of propagation than has been recorded in the British Isles; and it seems possible that an increment in the quality of "gustiness" may be produced in an air current by its passage over a very extensive surface whose friction coefficient is large. But this scarcely seems to throw ligbt upon the relation, mentioned by Sir R. Abercromby, between the gustiness of the wind for a given gradient over a particular and very limited area, and the velocity of propagation of the wind-system across that area.

The relation between the strength of the wind and the steepness of barometrical gradient is somewhat complex, and has not even yet received complete study. The relation between the strength of the wind and the velocity of propagation, or rate of progress of a storm, is a more intricate and obscure subject, and I believe that any facts which tend to elucidate it will be of considerable value, especially if this second relation can be shown to be independent of the first.

W. Clement Ley

$$
\text { March } 12
$$

\section{Strange Arithmetic}

IN the March number of the Contemporary Review is an article by Dr. C. B. Radcliffe, entitled "A Sequel to the Pedigree of Man," in which some most startling theories are pro. pounded. As an appendix to this article, he gives several tables intended to prove that the mean time of high spring-tide throughout the world is about six o'clock (morning and evening). For this purpose he gives the time at a considerable number of stations, and the very large discrepancies led me to inquire how he arrived at his results. This he does by adding the times together, and dividing by the number of places! It is surely clear that any miscellaneous selection of times treated in this manner must give a result somewhere near six.

His first table shows a result of $6 \mathrm{~h}$. $9 \mathrm{~m}$., but if you take his figures, and number the hours from morning to evening, instead of noon to midnight (that is, call six twelve, and twelve six), the result is $6 \mathrm{~h} .27 \mathrm{~m}$., or on our hypothesis 27 minutes past noon! The proper way of treating the figures would be to show at how many places the tide is high during each hour, and the annexed table shows that it is utterly impossible to fix any mean time. It all Dr. Radcliffe's theories rest on such hollow proofs as this,

\begin{tabular}{|c|c|c|c|c|c|c|}
\hline Hour. & & & able & & & Table Ir \\
\hline & $\ldots$ & $\cdots$ & 3 & $\ldots$ & $\ldots$ & \\
\hline 2 & $\cdots$ & $\ldots$ & 3 & $\ldots$ & $\ldots$ & 3 \\
\hline 3 & $\ldots$ & $\ldots$ & 4 & $\ldots$ & $\ldots$ & 2 \\
\hline 4 & $\ldots$ & $\ldots$ & 9 & $\ldots$ & $\ldots$ & 2 \\
\hline 5 & $\ldots$ & $\ldots$ & I & $\ldots$ & $\ldots$ & 3 \\
\hline 6 & $\ldots$ & $\ldots$ & 4 & $\ldots$ & $\ldots$ & 3 \\
\hline 7 & $\ldots$ & $\ldots$ & 7 & $\ldots$ & $\ldots$ & I \\
\hline 8 & $\cdots$ & $\ldots$ & 5 & $\ldots$ & $\ldots$ & I \\
\hline 9 & $\ldots$ & $\ldots$ & 0 & $\ldots$ & $\ldots$ & 7 \\
\hline IO & $\ldots$ & $\ldots$ & 2 & $\ldots$ & $\ldots$ & 2 \\
\hline I I & $\ldots$ & $\ldots$ & 2 & $\ldots$ & $\ldots$ & 6 \\
\hline I2 & $\ldots$ & $\ldots$ & 2 & $\ldots$ & ... & 2 \\
\hline & No. & laces & 42 & $\ldots$ & $\ldots$ & $\overline{3^{2}}$ \\
\hline
\end{tabular}
they are certainly worthy of little attention.

Chester, March 6

E. S.

\section{Fertilisation of the Grape Vine}

THE season is favourable for an examination of the floral development of the vine, and I recommend an inspection of the flower of that plant to all who are curious. For my own part I shall be glad if any one who has remarked more than is obvious will tell us something about it, for the flower is certainly remarliable. On examination it is seen that each little knob, which at first sight seems to be the young grape, is, in fact, a little green cap, which, when lifted off, discloses a group of stamens closely surrounding the pistil. To all appearance this cap-which is all that represents the flower (in the common acceptation of the word)-must effectually prevent anything like cross-fertilisation. Apparently it becomes detached below and is thrown off as soon as the stamens, which continue to support it, lose their vitality, and not before. It is, indeed, not easy to conceive any other so simple an arrangement, by which, whatever of fertilisation is necessary, can be ensured being done at home. It seems as if by this arrangement every flower must fertilise, though there were not another within miles, and cannot be fertilised by any other but itself, though it be one among thousands.

Collingwond, March I4

J. HERSChEL

\section{EXPLORATION IN BORNEO}

HERR CARL BOCK has successfully accomplished his journey across Borneo-from Koetei to Bandjermassing-arriving at the latter place on the last day of 1879. The journey was commenced on November $2 \mathrm{I}$, from Tangeroeng, the residence of the Sultan of Koetei, who promised to accompany Herr Bock, but did all in his power to dissuade him from going. From hence the route was up the Mahakkan River, to the village of Moara-Kaman, where the mosquitoes were so troublesome that a retreat was almost determined on. On the $24^{\text {th }}$ the largest Malay village in the interior was reachedKotta Bangoen, containing more than a thousand inhabitants. The whole of the lower part of the Mahakkan is occupied by the Malays, the Dyaks dwelling only on the smaller tributaries, or towards the source of the main river. In this neighbourhood there is abundance of rattang gutta, or edible birds' nests, and bees' wax, to obtain which the Malays go in parties of twenty or thirty into the forests for fear of the Dyaks. Owing to the great drought of last year in this district, the whole forest is leafiess, a very unaccustomed sight in the tropics, and as a result the birds had all deserted it, or at least none were to be seen. At this village, as well as at That is, r.o to $\mathrm{x} .59$ (morning or evening). 
Tangaroeng and Moara Kaman, Herr Bock has found traces of a former Hindoo race, and a Dyak had lately dug up a beautifully formed bronze Hindoo goddess. From this point Herr Bock diverged from the Mahakkan, in order to visit the lake district and observe the Dyak inhabitants. He has made a number of sketches of these savages, many of whom are cannibals. The most dreaded tribe are the Tring Dyaks, whose chief, by name Sibau Mobang, Herr Bock summoned to meet him in the name of the Sultan. This man is most villanous in looks, and told our traveller that he frequently cut off the heads of either sex for the sake of eating the brain, which was sweet, as were also the palms of the hands, but the shoulder was bitter; and he presented him with his shield, covered all over with tufts of human hair. At the last village in the Malay part of his dominions, Moara Pahou, the Sultan summoned a large number of the Dyaks to accompany him and accumulated a body of some 600 in all, of whom 75 accompanied Herr Bock one or two days' journey in advance. The Dyak tribes are constantly at war with each other in order to obtain heads, and the Malays look down on them as savages, and by this means the terror of their name is increased. The upper part of the Moara Pahou branch of the Mahakkan is broken by rapids, over which the praus had to be dragged by rattang ropes. The last village on this river, Moara Anar, was reached on December 20 , and then the march through the forest over the water-shed commenced. One of the advanced party was here killed, but no further loss was sustained. A Dyak road has been made through the forest with narrow bamboo bridges over the numerous small streams; these, however, were at the time mostly under water, owing to the recent floods. The journey on foot occupied four days of twelve bours, during two of which Herr Bock had to feed on the wild fruits, his provisions having been left behind. Perfect silence here reigns, broken only by the occasional note of a bird, though none are to be seen. No attempt at molestation appears to have been made by the more savage tribes of the Dyaks, although at one village the chief pressed his visitors to partake of rice and fruit, which they had been forewarned was poisoned, and therefore declined. The end of this march brought our traveller to the river Benangau, a tributary of the Tewé, down which he passed till he arrived on Dutch territory, where the Dyaks are altogether comparatively civilised, and very different to those of Koetei.

Very little that is new in zoology appears to have been obtained in this journey, which lay across a rather barren district; but Herr Bock has had splendid opportunities for making ethnological observations and these have been turned to good account. Many attempts were made to find the family which were said to have tails-but though several Dyaks were spoken to who had seen them, their whereabouts was not discovered.

The journey was undertaken at the desire of the Dutch government, who will doubtless take care that its successful accomplishment is duly honoured.

\section{THE AUDIPHONE}

$\mathrm{T}^{\mathrm{H}}$ $\mathrm{HE}$ instrument which is now being introduced into this country under the name of the audiphone, is the invention of Mr. R. G. Rhodes of Chicago. It is intended, as its name attempts to indicate, to provide the deaf with the means of hearing, and is for some persons undoubtedly a more efficient aid than the hearing-trumpet. The figures appended show the original form of the instrument, and the modification of it suggested by Prof. Colladon of Geneva. The American audiphone consists of a thin elastic plate or sheet of hard ebonite rubber, furnished with a handle, and about the size and shape of an ordinary palm-leaf fan. The string; attached to the upper edge serve to bend it into a curving form, and a small clamp fixes the string at the handle. When thus strained into shape, the instrument is pressed against the upper front teeth by the deaf operator, the convex side being turned outwards. The sounds received upon the thin sheet cause it to vibrate, and the vibrations are thus conveyed through the teeth and bones of the skull to the auditory nerves. Its use is therefore confined to the

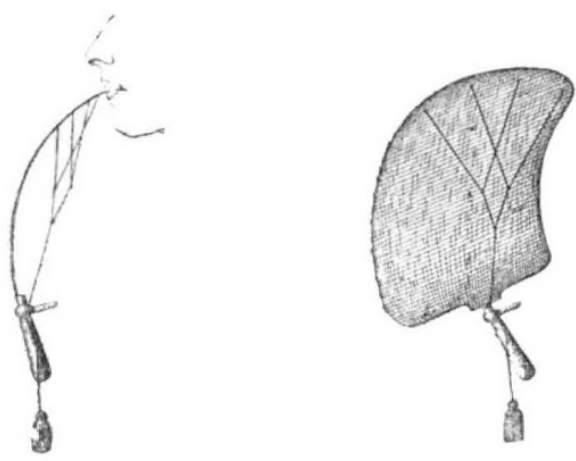

FIG. 1.-Rhodes's Audiphone.

partially deaf, or at least to those in whom the auditory sense is not entirely absent, or the nerve atrophied.

The ebonite of which the audiphone is made being costly, Prof. Colladon has suggested a cheap and efficient substitute in the form of a strip of elastic cardboard of the peculiar kind known to the trade as satin-board or shalloon-board, and which may be described as a fine kind of yellow mill-board with a very smooth, glazed surface.

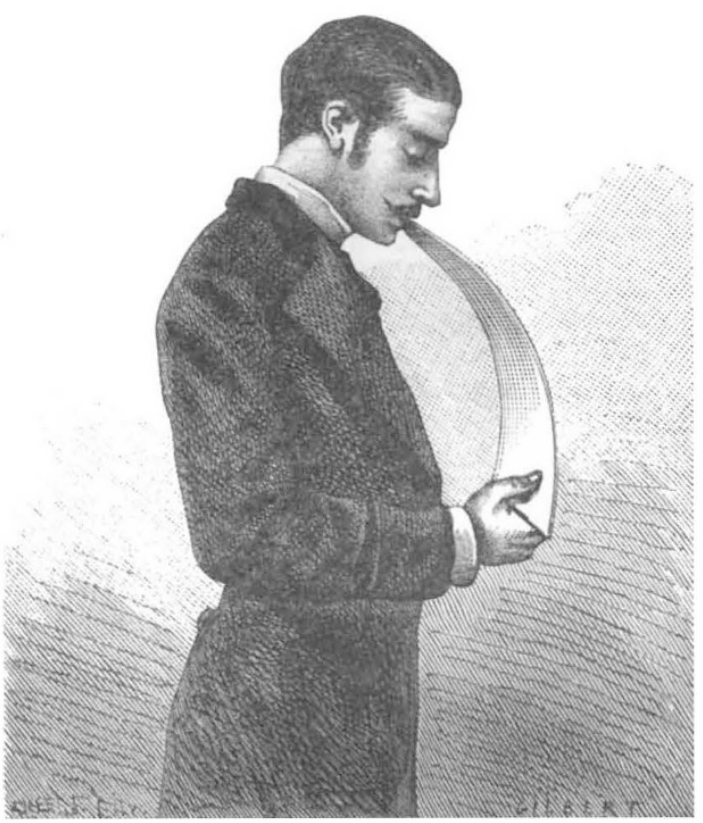

FIG. 2.-Colladon's Audiphone.

A sheet of this material, about eighteen inches long by ten broad, and varnished at the edge where it is placed in contact with the teeth, yields results quite equal, if not superior, to those afforded by the ebonite article of fifty times the cost. Prof. Colladon has made a number of experiments in conjunction with M. Louis Sager, upon the hearing of deaf-mutes. Not all who tried the instrument 